\title{
Educating the Reputation Capital Impact of a Region on the Parameters of Its Investment Activity: Methodical Approaches
}

\author{
Marat Rashitovich Safiullin ${ }^{1,2}$, Alexander Stanislavoich Grunichev ${ }^{1} \&$ Leonid Alekseevich Elshin ${ }^{2,3}$ \\ ${ }^{1}$ Kazan Federal University \\ ${ }^{2}$ State Budgetary Institution Perspective Economic Research Center, Academy of Sciences, Republic of Tatarstan \\ ${ }^{3}$ Kazan National University of Science and Technology \\ Correspondence: Marat Rashitovich Safiullin, Kazan Federal University. E-mail: Marat.Safiullin@tatar.ru
}

Received: July 17, 2019

Accepted: October 18, 2019

Online Published: October 28, 2019

doi:10.5430/ijhe.v8n7p146

URL: https://doi.org/10.5430/ijhe.v8n7p146

\begin{abstract}
As a practice and empirical observations show, the educational activity of economic agents forms a whole set of prospects for their development. It is due to stable positive or, on the contrary, negative expectations of prospective counterparts that interact with the economic agents, of the possibilities of their development in both the conjuncture and the institutional directions. In this regard, education is very important, and its study is becoming widespread in the research field. Meanwhile, it should be noted that the studies of the question posed in the space of scientific work and research mainly concentrate on the micro-level. That is, the vast majority of works are devoted to the study of the education of firms as one of the most important "representatives" of economic agents. At the same time, the study of educational capital and its influence on the development of regional / national economic systems is unfairly deprived of attention. It is necessary to state that in recent years, the attention of scientists began to focus more and more on the issues set earlier. However, the theory of the territories' educational economy has not yet received development and attention. This largely restrains the research paradigm based on the study of intangible factors of production in the system of socio-economic development of regions or national economic systems in general.

In this regard, and to level this gap, the time course of the reputation capital index for the Republic of Tatarstan and the main components determining its level are built in this paper based on the developed methodological approaches to a formalized assessment of the reputation of a territory. This allowed us to assess the reputation impact on the investment activity of a region using the methods of econometric modelling. In particular, being guided by the principles and tools of regression analysis, as well as relying on the method of dummy variables, a high level of interconnection between the studied parameters was established by the authors due to the significant level of elasticity between the analyzed series found.
\end{abstract}

Keywords: educational capital of a region, educational economy, investment activity, resources for the development of a region, business activity, globalization, econometric modelling

\section{Introduction}

One of the main trends of the last few decades predetermining the structural and economic transformation of the national / regional economies is the globalization of economic processes that are integrated into a single global value chain. This, in turn, forms a special institutional setting of their development. The most important factor in these conditions, which determines macroeconomic generation, is the educational capital of the territories, which forms the representation of economic agents in the field of building strategic behaviour models based on the generated expectations. In this regard, reputation can and must be attributed to the category of the most important factors determining the dynamics and quality of economic growth of national economies within the framework of emerging global competitiveness.

Other Russian scientists dealing with the problems of studying the reputation of territories adhere to a similar point of view. So, for example, in accordance with the approach by I.S. Vazhenina, region's reputation is "its peculiar and valuable enough asset, which is an objectively formed set of opinions of stakeholders in the region, one way or another connected with it (residents, investors, entrepreneurs, visitors, tourists, representatives of $~$ power, analysts, media, etc.) (Vazhenina, 2007; Henard \& Dacin, 2010) At present, it can be considered generally accepted that "the good reputation of a territory that has been built up over many years is a resource that can provide it with a 
sustainable competitive advantage promising strong partnerships. In this case, we interpret the "partnership" quite broadly, starting from the residence of a citizen in a given territory and the business contacts of regional entrepreneurs, to the region's participation in government projects, and in the implementation of inter-country initiatives and partnerships" (Vazhenina, 2007; Kabayeva et al, 2018; Mendonça \& Andrade, 2018; YILDIZ et al, 2017).

The content of the category "reputation of a region (territory)", as well as the category "image of a region" that is close to it, were considered in their works by A.P. Pankruhin, I.S. Vazhenina, P.V. Korchagin (Vazhenina \& Vazhenin, 2010; Vazhenina, 2013; Pankrukhin, 2008; Pankrukhin, 2010; Pankrukhin \& Ignatiev, 2008; Pankrukhin, 2008; Korchagin, 2012)

and others. In particular, a detailed study of the difference between the categories "image of a region (territory)" and "reputation of a region (territory)" can be found in (Vazhenina, 2010; Safiullin et al., 2011; https://docplayer.net). Foreign researchers hold similar points of view with Russian scientists (Roberts \& Dowling, 2002; Raithel \& Schwaiger, 2014; Shamsie, 2003; Fombrun \& Shanley, 1990; Hall, 1993; Roberts \& Dowling, 2002; Habibzadeh, 2016).

In the above works, the phenomena of the image and reputation of the regions were analyzed in a meaningful, qualitative manner. Meanwhile, the obtaining of quantitative estimates is no less important, primarily for practical purposes.

Unfortunately, there are not so many works devoted to this issue. And works that would offer and disclose methodological approaches to quantitative (formalized) assessment of the reputation of territories (regions) are not found at all in the research space. This kind of works restricts itself to either qualitative analysis of the subject and objects of study, or, for example, such methods of analysis as sociological research, expert assessments, etc.

\section{Methods}

The methodological concept of determining the educational capital index is based on the construction of a series of sub-indexes characterizing the territory's educational activity in the global information space. The basis of this approach is the construction and quantitative modelling methods of the institutional and conjunctural environment assessed by economic agents and reflected in the system of information assessments that are dynamically generated in the global information space. Their recording allows us to determine the fundamental level of expectations of economic agents regarding the prospects and quality of the socio-economic development of the object under study.

The region's reputation is assessed based on 5 key sub-indices (Figure 1).

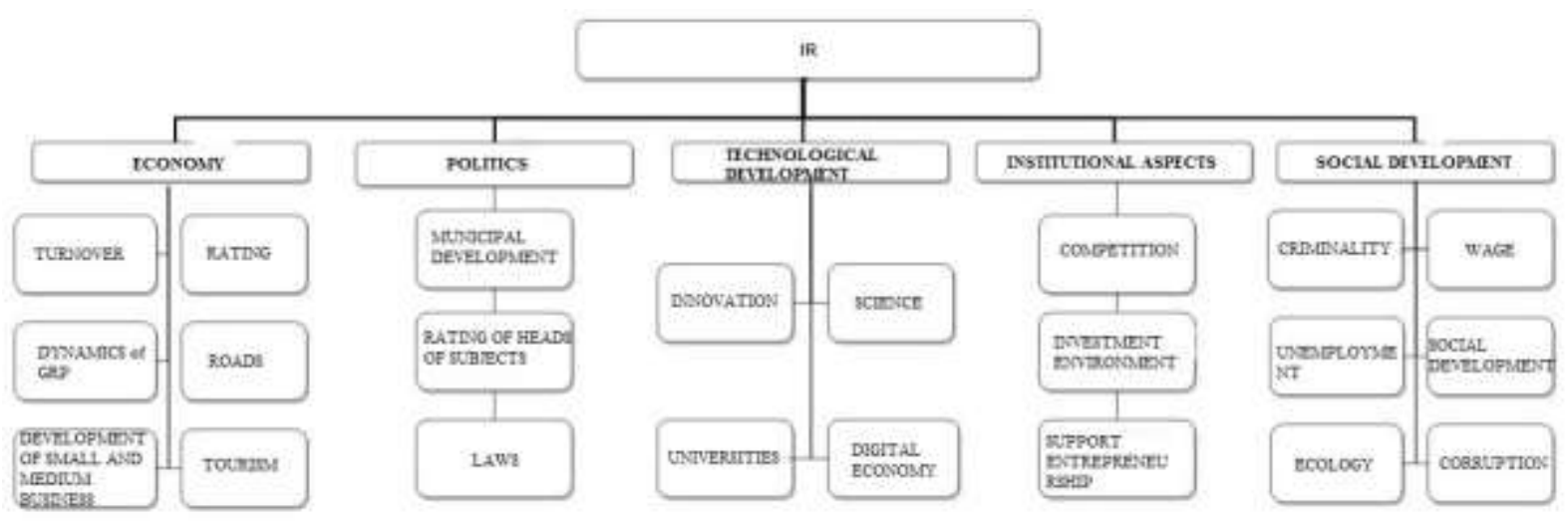

Figure 1. The system of search requests that form the image (idea) of the reputation of a territory (region)

The basis of the algorithm for calculating the values of sub-indexes that evaluate a particular aspect of a region's reputation is the implementation of a series of iterations.

Iteration 1. Identification of the search request wordings which develop the image and potential of the region.

Iteration 2. Determination of the request's popularity in the external environment. This stage of the study involves an assessment of the tonality of information search results taking into account the information source level (federal / regional media), as well as the probability of the link to follow. The implementation of this procedure is carried out 
in the context of the analyzed search engines (Google, Yandex, Mail.ru, etc.). In a structured form, the implementation process of the considered iteration can be represented as table 1 .

Table 1. An example of implementing the determination of the result's popularity in the external environment

\begin{tabular}{ccccc}
\hline Line number & $\begin{array}{c}\text { Transition } \\
\text { probability }\end{array}$ & Key & $\begin{array}{c}\text { Information } \\
\text { source level } *\end{array}$ & Actual place in request results \\
\hline 1 row & $26.90 \%$ & + & 1 & 1 \\
2 row & $17.10 \%$ & - & 1 & 2 \\
3 row & $14.90 \%$ & - & 1 & 3 \\
4 row & $8.90 \%$ & + & 2 & 5 \\
5 row & $7.10 \%$ & + & 1 & 7 \\
6 row & $4.70 \%$ & + & 1 & 8 \\
7 row & $5.60 \%$ & - & 2 & 9 \\
8 row & $5.10 \%$ & + & 1 & 10 \\
9 row & $4.70 \%$ & + & 1 & 12 \\
10 row & $4.70 \%$ & + & + & 15 \\
\hline
\end{tabular}

* 1 - federal source of information; 2 - regional source of information.

Iteration 3. In the context of each search engine participating in the procedure of analyzing the region's reputation capital, the coefficient "The result's popularity in the external environment $\left(\mathrm{K}_{\mathrm{f}}\right)$ according to formula 1 is estimated.

$$
\operatorname{Krp}=\sum P_{j} \times I j
$$

Where

$\mathrm{K}_{\mathrm{rp}}$ - the request popularity coefficient;

$\mathrm{j}$ is the request number;

$P_{j}$-the probability of clicking the j-th row of the request result;

$\mathrm{I}_{\mathrm{j}}$ - information source level (federal / regional).

Taking into account the underlying algorithm, the range of possible values of the coefficient is from $-1,994$ to $+1,994$.

Iteration 4. Evaluation of the region's reputation capital for a search request (Determining the reputation of a result in Runet (within search engines: Google, Yandex, Mail.ru, etc.)

The values of this indicator are calculated according to the formula.

$$
K_{r a}=\sum T_{k} \times K_{p} \times V i
$$

Where

$\mathrm{K}_{\text {r.a }}$ - Educational activity coefficient of the region according to the search request;

$T_{k}$ - Tonality of the search engine;

$K_{p}$ - Popularity of the request;

$\mathrm{Vi}$ - Search engine's share in Runet.

Tonality of the search engine is understood as a system of assessments of the analyzed subject concerning the region's educational activity determined based on an analysis of positive and negative evaluations of the search request. The value of the coefficient $\mathrm{T} \mathrm{k}$ is determined by the formula 3 .

$$
\mathrm{T} k=(\mathrm{T}+\mathrm{i}-\mathrm{T}-\mathrm{i}) / 10
$$

Where

$\mathrm{T}_{+\mathrm{i}}$ - the number of positive ratings issued for a search request in the analyzed search engine;

$\mathrm{T}_{-\mathrm{i}}$ is the number of negative ratings issued for a search request in the analyzed search engine; 
$\mathrm{i}$ - the number of search engines involved in the study.

The value 10 in the denominator is determined by the number of search engine responses to the request being analyzed and included in the analytical database. As mentioned earlier, the inclusion in the analysis of the number of responses to a request that exceeds 10 is impractical because of the low probability of users clicking on them (less than $3-5 \%)$.

The most important component involved in formula 3 is the index characterizing the search engine's share in Runet. This index acts as a kind of weighting factor and demonstrates the role of the search engine in determining the values of the region's reputation capital within a single search request.

Iteration 5. Calculation (quantitative assessment) of the sub-index characterizing a particular aspect of the region's reputation capital.

The indicator value assessment is carried out as the sum of products of weighted coefficients of the region's educational activity. Formula-type definition of sub-indices is as follows:

$$
I_{r_{i}}=\sum \mathrm{K} r . a \times w_{i}
$$

Where

$\mathrm{I}_{\text {ri }}$ - Aggregated sub-index of regional educational activity;

Kr.a - Coefficient of the region's educational activity for a search request;

$w_{i}$ - Share of requests in RuNet within the analyzed number of search requests. It is determined based on statistics of requests (Safiullin et al., 2011)

$\mathrm{i}$ - the number of sub-indices participating in the study.

Iteration 6. Calculation of the integral index of the region's educational activity:

$$
R=\sum \operatorname{Ir} i \times w_{i}
$$

Where

$\mathrm{I}_{\text {ri }}$ - aggregated sub-index of the region's reputation activity;

$w_{i}$ - the weighting factor value defined as the proportion of the number of hits on the search request to the sum of users hits on the requests analyzed in the study.

The most important methodological aspect being formed within the framework of the developed research concept on the territory's educational capital is the factor analysis of the weighting factors under the sub-indices that form the basis for calculating the integral index of the territory's educational capital.

\section{Results and Discussion}

Based on the above tools, the integral values of the reputation capital index for the Republic of Tatarstan for the period from 2010 to 2017 were obtained as a result of the estimates and calculations implemented (Table 2, Figure 2). 
Table 2. Time course of the reputation capital index of the Republic of Tatarstan ( $\mathrm{I}_{\mathrm{RC}}$ ) and the main components determining its level

\begin{tabular}{|c|c|c|c|c|c|c|c|c|}
\hline Sub-index name & 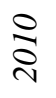 & $\underset{\sim}{\grave{D}}$ & $\underset{\sim}{\stackrel{2}{\sim}}$ & 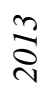 & $\underset{\sim}{\stackrel{\nabla}{2}}$ & 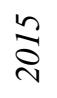 & $\stackrel{\circ}{i}$ & $\lesssim$ \\
\hline $\begin{array}{l}\text { Reputation of the region in the economic } \\
\text { area }\end{array}$ & 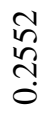 & $\stackrel{\sim}{\stackrel{2}{0}}$ & \begin{tabular}{l}
$\infty$ \\
\multirow{0}{0}{} \\
$\stackrel{0}{0}$
\end{tabular} & $\stackrel{\infty}{\stackrel{\infty}{0}}$ & $\stackrel{\tilde{n}}{\tilde{c}}$ & 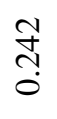 & กิ & ๙ิ \\
\hline $\begin{array}{l}\text { Reputation of the region in the social } \\
\text { development area }\end{array}$ & 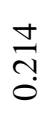 & 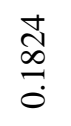 & $\frac{\dot{\sigma}}{\stackrel{\sigma}{0}}$ & $\underset{\hat{N}}{\tilde{\sigma}}$ & $\stackrel{\overbrace{}}{\circ}$ & $\frac{1}{0}$ & 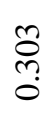 & $\stackrel{n}{?}$ \\
\hline $\begin{array}{l}\text { Reputation of the political (managerial) } \\
\text { development of the region }\end{array}$ & $\stackrel{f}{\stackrel{f}{\sigma}}$ & $\begin{array}{l}\stackrel{\bullet}{\oplus} \\
\stackrel{0}{0} \\
0\end{array}$ & $\stackrel{n}{\dddot{2}}$ & $\stackrel{\infty}{8}$ & $\stackrel{\overrightarrow{0}}{\circ}$ & $\stackrel{\Xi}{0}$ & $\stackrel{8}{8}$ & $\stackrel{n}{8}$ \\
\hline $\begin{array}{l}\text { Reputation of the technological } \\
\text { development of the region }\end{array}$ & $\begin{array}{l}\stackrel{2}{n} \\
\\
0\end{array}$ & 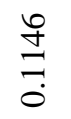 & $\stackrel{m}{\Xi}$ & $\stackrel{\infty}{\stackrel{\infty}{\div}}$ & $\stackrel{\infty}{\circ}$ & $\frac{\mathrm{N}}{\mathfrak{0}}$ & $\begin{array}{l}\circ \\
\stackrel{0}{0} \\
\stackrel{0}{0}\end{array}$ & $\stackrel{0}{=}$ \\
\hline $\begin{array}{l}\text { Institutional aspects of the region's } \\
\text { reputation }\end{array}$ & 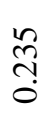 & 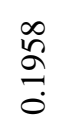 & $\frac{\stackrel{g}{+}}{\stackrel{\sim}{o}}$ & $\begin{array}{l}\stackrel{0}{0} \\
\stackrel{0}{0}\end{array}$ & 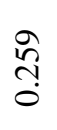 & $\stackrel{F}{\circ}$ & $\hat{\widehat{o}}$ & 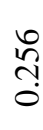 \\
\hline $\begin{array}{c}\text { Integral value of the region's reputation } \\
\text { capital index }\end{array}$ & 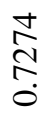 & $\begin{array}{l}\stackrel{0}{\circ} \\
\stackrel{0}{0}\end{array}$ & $\begin{array}{l}0 \\
\text { பे } \\
\infty \\
0\end{array}$ & $\begin{array}{l}\vec{\varpi} \\
\infty \\
0\end{array}$ & $\begin{array}{l}n \\
\infty \\
0 \\
0\end{array}$ & $\frac{\hat{n}}{\hat{\sigma}}$ & $\begin{array}{l}\mathfrak{2} \\
\stackrel{0}{0}\end{array}$ & $\begin{array}{l}+ \\
\stackrel{\infty}{\circ} \\
0\end{array}$ \\
\hline
\end{tabular}

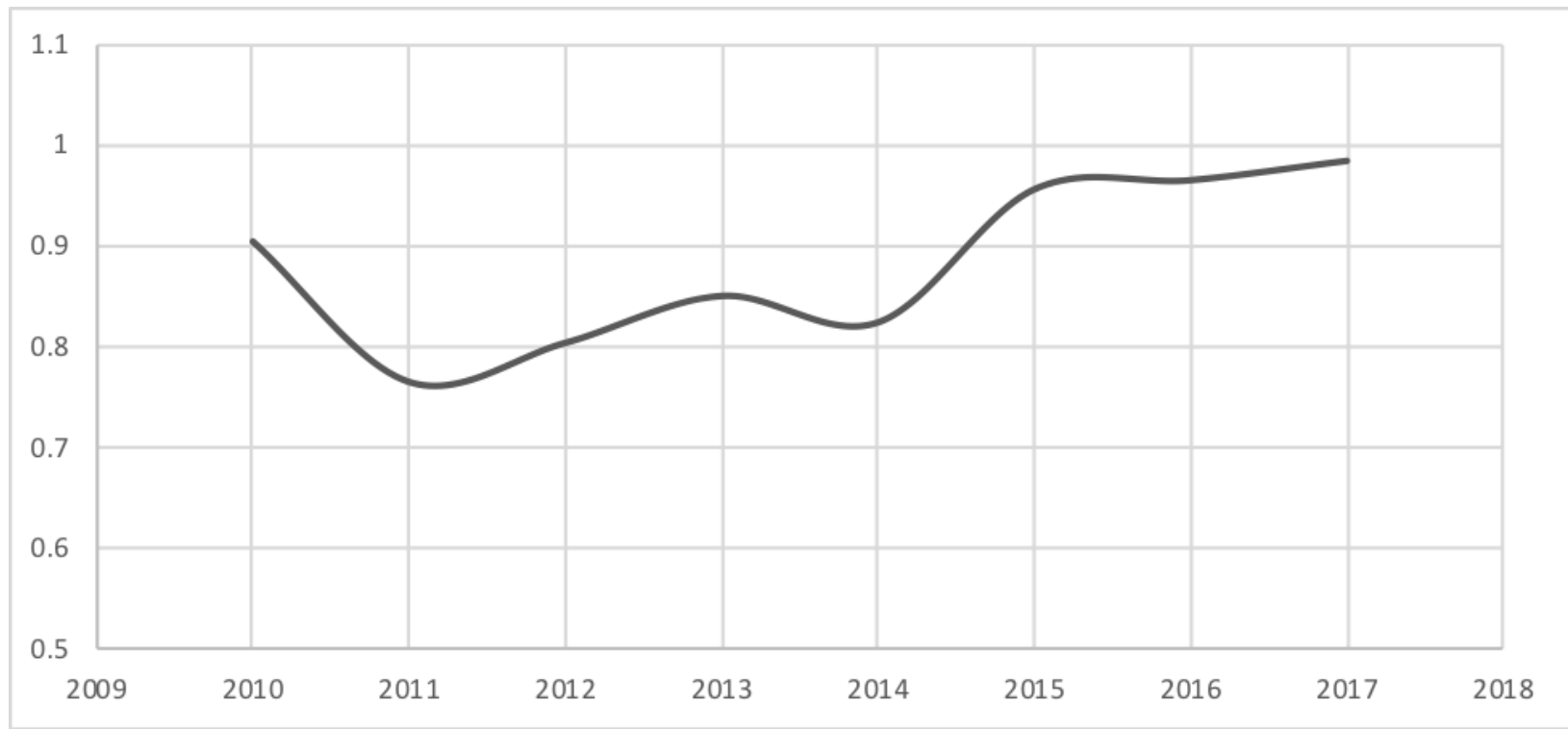

Figure 2. Time course of the educational capital of the Republic of Tatarstan $\left(\mathrm{I}_{\mathrm{RC}}\right)$ and the main components determining its level

The obtained estimates of the time course component of the Territory's Reputation Capital Index make it possible proceeding to the most important stage of the study, namely, identification of the relationship between the level of a region's reputation and the parameters of its socio-economic development. At the same time, an important step in the identification algorithm of the interrelations under consideration is the search and definition of a system of statistical 
indicators that would serve as the resultant in the process of a dynamic change in the region's educational activity. In our opinion, the capital investment growth index can be a key indicator here.

To assess the reliability of the use of the above logic on the relationship between the region's reputation capital index and the capital investment growth, a regression analysis was implemented, the results of which are presented in Table 3. Calculations were carried out by the example of the Republic of Tatarstan.

The result of implementing the calculated iterations series based on the dummy variables method was the regression model which acquired the following form (1):

$$
\mathrm{I}_{\%}=-1.32+0.59 \mathrm{I}_{\mathrm{RC}}+1.52 \mathrm{~F} 1+1.05 \mathrm{~F} 2
$$

Where:

I $\%$ - the growth rate of capital investment, in \% of the previous year;

$\mathrm{I}_{\mathrm{RC}}$ - integral index of the region's educational activity;

F1, F2 - dummy variables.

The obtained parameters which characterize the statistical significance of the obtained regression model with two dummy variables, demonstrate its very high level of confidence $\left(\mathrm{R}^{2}=0.81\right.$; $\mathrm{p}$-criteria values are less than the specified level of significance 0.05 ).

\section{Summary}

The presented estimates and calculations demonstrate a high level of verification of the constructed model. This allows us to form an evidence base that there is a unique relationship between the level of a federal subject's educational activity and the parameters of its socio-economic development. At the same time, using the example of the Republic of Tatarstan, we have proved that with the growth of the reputation index by 1 percentage point the dynamics of growth of capital investment reaches a growth of 0.59 p.p. Thus, there is every reason to assert that there is a close relationship between the studied parameters due to the significant level of elasticity between them. In other words, insignificant fluctuations of the region's reputation capital form a noticeable reaction in the field of investment activity of economic entities.

\section{Conclusions}

In general, it should be noted that educational capital plays a significant role in the process of socio-economic development of regions, as evidenced by the obtained calculations. Availability of special means and methods capable of positively influence the level of the territory's educational capital opens up additional tools and opportunities for intensifying regional socio-economic development. However, the solution of this type of task is very non-trivial in nature and requires not only the use of special skills and abilities on the part of executive authorities in the development of the so-called "educational economy", but, first and foremost, will largely depend on the understanding and "recognition" of key factors determining the reputation of the territory. The tools for assessing the educational capital of a region developed in this study make it possible to quite effectively identify such factors and, on this basis, develop adaptive methods and ways to increase the regional educational capital level. As the study showed, this will make it possible to activate economic growth dynamics through the intensification of investment processes in the economy.

\section{Acknowledgements}

The work is performed according to the Russian Government Program of Competitive Growth of Kazan Federal University.

The publication was prepared within the framework of the research project No. 19-010-00211 supported by the Russian Foundation for Basic Research (RFBR)

\section{References}

Fombrun, C. \& Shanley, M. (1990). What's in a name? Reputation building and corporate strategy. Academy of Management Journal, 33(2), 233-258.

Habibzadeh, M. (2016). Legal Strategies of money Laundering Prevention Emphasizing Financial -Economical policies. UCT Journal of Social Sciences and Humanities Research, 4(2), 26-30

Hall, R. (1993). A framework linking intangible resources and capabilities to sustainable competitive advantage. Strategic Management Journal, 14(8), 607-618. 
Henard, D. \& Dacin, P. (2010). Reputation for product innovation: Its impact on consumers. Journal of Product Innovation Management, 27(3), 321-335. http://dx.doi.org/10.1111/j.1540-5885.2010.00719.x

Kabayeva, Z., Mussabaev, S. \& Madalieva, Z. (2018). The formation way of independent Kazakhstan from the individualism and collectivism perspective. Opción, 34(85-2), 706-728.

Korchagin, P. V. (2012). Economic and Social Development of the Territory: Methodological and Applied Aspects. Thesis for a doctorate in economics. Togliatti State University of Service. - Tolyatti: Volga State University of Service, 491, 91-102.

Mehmet Lutfi Arslan and Sadi Evren Seker Web Based Reputation Index of Turkish Universities. (2014). International Journal of e-Education, e-Business, e-Management and e-Learning, 4(3), C.197-203. URL: https://docplayer.net/8905723-Web-based-reputation-index-of-turkish-universities.html (access date: 04.03.2019)/

Mendonça, C. M. C. D. \& Andrade, A. M. V. D. (2018). Dynamic Capabilities and Their Relations with Elements of Digital Transformation in Portugal. Journal of Information Systems Engineering \& Management, 3(3), 23.

Pankrukhin, A. P. (2008). Counter-marketing. De-branding and destruction of the image of a territory. Corporate imageology, 23, 12 - 15.

Pankrukhin, A. P. (2008). The best cities for business. How much did Forbes manage to assess the convenience of Russian cities?. Corporate Imageogology, 3, 76 - 77.

Pankrukhin, A. P. (2010). Subjects and approaches in the marketing of territories: difficult coordination of positions / In Coll.: The Image of a Country. region as a strategy for the integration of Russia and the APR countries in the XXI century. Materials of the All-Russian scientific and practical conference with international participation. Executive editor: Kuzmin A.V. - Ulan-Ude: East Siberian State University of Technology and Management Publishing, 17-21.

Pankrukhin, A. P. \& Ignatiev, S. (2008). Image of a country: Paradigm Shift. Views from Canada, Russia, Great Britain, and Latvia. Corporate Imageology, 2, 8-14.

Raithel, S. \& Schwaiger, M. (2014). The effects of corporate reputation perceptions of the general public on shareholder value. Strategic Management Journal, 36(4), 945-956. http://dx.doi.org/10.1002/smj.2248

Roberts, P. W. \& Dowling, G. R. (2002). Corporate reputation and sustained superior financial performance. Strategic Management Journal, 23(12), 1077-1093.

Roberts, P. W. \& Dowling, G. R. (2002). Corporate reputation and sustained superior financial performance. Strategic Management Journal, 23(12), 1077-1093.

Safiullin, M. R., Elshin, L. A. \& Shakirova, A. I. (2011). On the Assessment of Business and Economic Activity. Moscow, 111

Shamsie, J. (2003). The context of dominance: An industry-driven framework for exploiting reputation. Strategic Management Journal, 24(3), 199-215. http://dx.doi.org/10.1002/smj.291

Vazhenina, I. S. (2007). Conceptual bases of formation and improvement of the region's reputation. Regional Economy: Theory and Practice, 8.

Vazhenina, I. S. (2010). Image and reputation of the territory. Regional economy. Theory and Practice, 23, 2-12.

Vazhenina, I. S. (2013). Image, Reputation and Brand of a Territory. Ekaterinburg: Institute of Economics. Ural Branch of the Russian Academy of Sciences, 378.

Vazhenina, I. S. \& Vazhenin, S. G. (2010). Image and reputation as strategic components of intangible assets of the territory. Economy of the Region, 3, 95-103.

YILDIZ, S., ALTAY, N. \& TORUNER, E. K. (2017). Health, Care and Family Problems in Gifted Children: A Literature Review. Journal for the Education of Gifted Young Scientists, 5(3), 15-24. 